Session 2354

\title{
Engineering Entrepreneurship: Does Entrepreneurship Have a Role in Engineering Education?
}

\author{
Steven P. Nichols, Neal E. Armstrong \\ College of Engineering \\ The University of Texas at Austin
}




\title{
Engineering Entrepreneurship: Does Entrepreneurship Have a Role in Engineering Education?
}

\author{
Steven P. Nichols, Neal E. Armstrong \\ College of Engineering \\ The University of Texas at Austin
}

\begin{abstract}
Many engineering programs have recently added courses and material on "Engineering Entrepreneurship". These programs represent a diverse understanding of what engineering students should receive in the way of instruction in the area of entrepreneurship. This paper examines various definitions of engineering entrepreneurship and also examines the pedagogical justification for including entrepreneurship in engineering education.

The authors use as a context the engineering programs at The University of Texas at Austin, particularly the Department of Mechanical Engineering. The paper examines educational objectives and criteria discussed in documents produced by the National Science Foundation, the American Society of Mechanical Engineering International, the Accreditation Board for Engineering and Technology, and other sources to develop one approach for entrepreneurship education.
\end{abstract}

\section{Introduction}

The last 50 years have seen significant improvement in the education of engineering students. Since the Grinter report in 1952, ${ }^{1,2}$ engineering education programs across the United States have undertaken to improve the educational experience of engineering undergraduates by seeking a rational mix of courses and educational experiences in science, engineering science, engineering analysis and engineering design. Prior to the Grinter report engineering education in the United States emphasized design with an insufficient mixture of science, engineering science, and engineering analysis. ${ }^{3}$ Engineering programs significantly increased the content of science and analysis courses over the last 50 years to provide a stronger analytical base for engineering practice.

Literature in the 1980's and 1990's includes articles recommending increased exposure for undergraduate engineering students in the area of design and creativity. ${ }^{4}$ Peterson argued that engineering sciences and engineering analysis had been segregated from engineering design to the extent that graduates are unable to apply their analytical skills to real problems. ${ }^{5}$ Engineering faculty have examined not only what and when topics and areas are taught to undergraduates, ${ }^{6}$ but also how these topics are taught. ${ }^{7}$ 
As part of this examination and evolution of engineering education, some engineering programs are offering course material and curriculum in Entrepreneurship. ${ }^{8}$ The remainder of this paper examines the pedagogical justification for including entrepreneurship in engineering education.

\section{Definitions}

When examining this question, it is critical to define terms. The authors will start with the definition of "Entrepreneur". Merriam Webster's Dictionary defines entrepreneur as follows:

\section{Definition 1. "Entrepreneur--- one who organizes, manages, and assumes the risks of a business or enterprise".}

Starting with this definition, it is difficult to conclude that the study of Entrepreneurship should take place in a college of engineering as opposed to a college of business administration. Topics of personnel and asset management, accounting, finance, marketing, advertising, asset management and faculty better handles related topics in business. Furthermore, it is not immediately clear what engineering topics emerge from general entrepreneurship. The risks and challenges of starting and operating a dry cleaning business or a sporting goods store does not appear to fit into an engineering educational program.

One may, however, come to a different conclusion if one examines an altered definition.

\section{Definition 2. Engineering (or Technology) Entrepreneur: One who organizes, manages, and assumes the risk of an engineering (or technology) business or enterprise.}

The second definition may require engineering research, analysis, development, design, and assessment that could reasonably be offered in a College of Engineering. The reader will note that the second definition also requires a broad range of background not normally found in engineering curriculum. Now the question becomes, should an engineering education program offer specific material in support of "one who organizes, manages, and assumes the risk of an engineering (or technology) business or enterprise"? One way of examining this question is to question whether "Engineering Entrepreneurship" is consistent with the educational mission of an engineering college.

The authors propose that the answer to this question will depend upon the educational mission of specific engineering programs. This paper will examine the question in the context of the engineering education programs at The University of Texas at Austin (UTAustin).

\section{College of Engineering Considerations}

The College of Engineering at UT-Austin undertook an examination of the following question: 
What (if anything) should the College of Engineering do in Engineering Entrepreneurship??

-For engineering students with special interests in Engineering Entrepreneurship

-For all engineering students, including

- Students with interests in graduate study in engineering

- Students with interest in working in large corporations

- Students with interest in working in small business

Internal Guidance

The College organized a Task Force consisting of engineering faculty as well as external advisors $^{10}$ to examine the question. In addressing the question of Engineering Entrepreneurship, the Task force sought guidance from the Strategic Plans both of the College and of departments. These strategic plans were previously developed by faculty with the input and guidance of "customers" of the College and the Departments.

Not surprisingly, the various strategic plans (department and College) shared core elements, but each department had its own emphasis. For the purposes of this paper, the discussion will be limited to looking at the Strategic Plan of the Department of Mechanical Engineering (ME). 
The ME Strategic plan includes the following components:

Mission:

-Educate the next generation of leaders in the Mechanical Engineering profession

-Create, explore, and develop innovations in engineering science and technology

-Provide beneficial service to the local, state, national, and international communities.

Core Values

Leadership and Innovation

The plan emphasizes and values Creativity, Novel Application of Fundamental Engineering Science, Interdisciplinary Activities, Community of Scholars, Development of Future Leaders, Professionalism, and Excitement in Discovery

Values

Creativity

Novel Application of Fundamental Engineering Science

Interdisciplinary Activities

Community of Scholars

Development of Future Leaders

Professionalism

Excitement in Discovery

Source: Mechanical Engineering Strategic Plan, Revised, April 2000.

Empahsis added.

\section{External Guidance}

Accreditation Board for Engineering and Technology.

The Task Force also examined Criteria developed by the Accreditation Board for Engineering and Technology. The following criteria were particularly useful.

ABET requires that students demonstrate ${ }^{11}$

(a) an ability to apply knowledge of mathematics, science and engineering

(b) an ability to design and conduct experiments, as well as to analyze and interpret data

(c) an ability to design a system, component, or process to meet desired needs

(d) an ability to function on multi-disciplinary teams

(e) an ability to identify, formulate, and solve engineering problems

(f) an understanding of professional and ethical responsibility

(g) an ability to communicate effectively

(h) the broad education necessary to understand the impact of engineering solutions in a global and societal context

(i) a recognition of the need for, and an ability to engage in life-long learning

(j) a knowledge of contemporary issues

(k) an ability to use the techniques, skills, and modern engineering tools necessary for engineering practice.

Needs of Industry and Commerce.

Proceedings of the 2001 American Society for Engineering Education Annual Conference \& Exposition Copyright 2001, American Society for Engineering Education. 
The Task force also considered the needs of industry as reflected in the membership of the Engineering Foundation Advisory Council and other sources. As an example, the Task force referred to Mechanical Engineering in the $21^{\text {st }}$ Century: Trends Impacting the Profession. ${ }^{12}$ The report identified the following "important" skills relevant that Engineering Entrepreneurship could support: ${ }^{13}$

\section{Excerpts from Mechanical Engineering in the $21^{\text {st }}$ Centruy}

\begin{tabular}{|l|l|}
\hline Important "Hard" Skills & Important "Soft Skills \\
\hline Use of new Materials & Effective communication \\
\hline Ability to apply new technology & Teamwork \\
\hline Abstract thinking & Multicultural \\
\hline Business skills & Flexibility \\
\hline Practical Experiences & Professional Ethics \\
\hline & Creative thinking \\
\hline & Respect and courtesy \\
\hline & Leadership skills \\
\hline & Compassion for others \\
\hline & Patience \\
\hline
\end{tabular}

The Report also forecast rapidly increasing "entrepreneurial activity throughout the global economy" and a "fast-growing employment in small and medium size firms and in selfemployment in engineering". ${ }^{14}$ The report further suggest a general change of the engineer from the "employee mentality to the entrepreneurial mentality. ${ }^{15}$ The increasing use of engineers for as contractors (Cf. Engineers as employees) supports this conclusion.

Task Force Observations:

The Task Force concluded that the College should support and encourage curriculum and courses in Engineering Entrepreneurship if designed to support the educational concepts consistent with College and departmental priorities: technical excellence, leadership, innovation, exploration, professionalism, and excitement in learning (discovery). Additionally, the Task Force observed that courses and material in Engineering Entrepreneurship could be designed to assist engineering programs address the ABET criteria found in bold in the list above as well as the needs of the industrial and commercial sector that engineering graduates tend to serve.

\section{Approach of the College of Engineering}

The considerations discussed above support a conclusion that topics of Engineering Entrepreneurship are consistent with the education mission, the research mission, and the public service mission of a college of engineering. The current version of the College of Engineering Strategic Plan includes the following goal:

Goal 3: Foster innovation in engineering research and practice, encourage entrepreneurship and promote leadership in engineer's service to society. 
Based upon these conclusions, the College of Engineering at UT-Austin has developed approaches for research, education, and public service. The College has developed following education approaches towards Engineering Entrepreneurship in the classroom.

For Students with special interests in Engineering Entrepreneurship

The College has developed undergraduate and graduate courses in Engineering Entrepreneurship. The latest course, "From Lab to Market" is a graduate level course that presents an organized approach to entrepreneurship and relates market needs to current university research activities. The course is cross-listed in the School of Business, the College of Natural Sciences, the School of Law, and the College of Engineering. The students work in interdisciplinary teams in developing their approach to the commercialization of specific technologies. The course includes a series of guest speakers that add the pragmatic approach the engineering enterprise. The guest lectures are open to other faculty, staff, students, and the broad community that UT-Austin serves.

For all engineering students.

Integration of the material in the undergraduate curriculum ostensibly presents a more difficult question and a more difficult task. Engineering Entrepreneurship curriculum material intended for a broad spectrum of engineering students can, however, enhance the general education received by these students. As an example, faculty can define capstone engineering design problems in a broad context which not only requires students to "design a system component, or process to meet desired needs" but also to realize the "broader implications" of their designs in a "global and societal context". Faculty can (and perhaps should) teach engineering economics in the context of the engineering enterprise that many students will later experience in their professional career. Even during the freshman year, students can study the engineering design process in the context of the Engineering Enterprise that helps them understand professional and ethical responsibility and the need to communicate clearly and effectively. The authors do not suggest that engineering programs must expose all their students to Engineering Entrepreneurship. In fact, all of the students in engineering programs at UT-Austin currently do not experience such exposure. The authors are suggesting that Engineering Entrepreneurship offers rich pedagogical opportunities to address many of the topics of interest to engineering educators (as listed in ABET Criteria (a) through $(\mathrm{k})$ listed above) and to encourage an education and research culture which promotes innovation, creativity, and leadership.

\section{Conclusion}

The toolbox is growing vastly; this removes limitations on the engineer. What is possible threatens to outpace people's knowledge of how to realize it.

Dr. Winfred Phillips ${ }^{16}$

The paper establishes pedagogical justification for including in engineering curricula both courses and material in Engineering Entrepreneurship. Experiences in Engineering 
Entrepreneurship can provide a framework for addressing engineering problems in a societal context. For UT-Austin, Entrepreneurship can also help develop concepts of leadership, innovation, and creativity that serve as core values both for the College of Engineering and for various departments.

The College of Engineering has developed (and continues to develop) courses, course material, and experiences to provide undergraduate and graduate students in engineering the opportunity to better understand the Engineering Enterprise. Many of these experiences are being developed specifically for students with specific interests in Entrepreneurship. These experiences include concepts of starting and running a technology business.

The College also is developing curriculum material for a broader cross-section of students. As listed above, the Department of Mechanical Engineering has identified core values of leadership and innovation. These are characteristics important in Engineering Entrepreneurship, and they are important in start-up and small engineering businesses. They are also, however, qualities needed for engineering work in any technology business. The same is true for the other values listed above: creativity, novel applications of fundamental engineering science, interdisciplinary activities, community of scholars, development of future leaders, professionalism, and excitement in discovery. Conceptually placing the engineering student in the position of the decision maker in her own company encourages the student to better develop the professional skills necessary in today's workplace. This also encourages students to better understand customer needs that drive the products and services that engineers create. Engineering itself is a creative process. The practice of engineering has an inherent (and unavoidable impact on society. As a result, design problems inherently include at least some issues of professional responsibility. ${ }^{17}$

Many of these values are also reflected in ABET criteria previously cited. Engineering education programs across the United States struggle with how to develop course and curriculum material found in ABET Criteria 2, Items a-k. Davis has stated, "We have come to believe that professional ethics should be taught in a way most likely to bring home to students that ethics problems do not come free-standing in practice. They are integral to what professionals do." ${ }^{18}$ Teaching concepts in Engineering Entrepreneurship offers a promising mechanism to expose students to the professional responsibility of engineers while at the same time developing improved skills of product realization driven by customer requirements.

\section{References and Notes}

${ }^{1}$ Grinter, L. E. (ed.), "Report on Evaluation of Engineering Education," Journal of Engineering Education, 1952.

2 See the Discussion in Efatpenah, K. Nichols, S., Weldon, W., "Design in the Engineering Curricula: A Changing Environment, Advances in Capstone Education: Fostering Industrial Partnerships, August 3-5, 1994.

${ }^{3}$ See comments in Efatpenah, K. Nichols, S., Weldon, W., "Design in the Engineering Curricula: A Changing Environment, Advances in Capstone Education: Fostering Industrial Partnerships, August 3-5, 1994. 
${ }^{4}$ See for example:

Augustine, Norman, Vest, Charles M. (Editors), Engineering Education for a Changing World, A joint project by the Engineering Deans Council and Corporate Roundtable of the American Society for Engineering Education, ASEE, October 1994,

Chaplin, C., "Creativity in Engineering Design---The Educational Function," The Education and Training of Charted Engineers for the 21st Century, A Study Undertaken for the Fellowship of Engineering 2 Little Smith Street, Westminster, London, November, 1989,

Brereton, Margot F, et al, An Exploration of Engineering Learning, DE-Vol. 53,m Design Theory and Methodology, ASME, 1993.

${ }^{5}$ Peterson, Carl R., "The Desegregation of Design", Engineering Education, pp. 530-532, July/August, 1990.

${ }^{6}$ See for example:

Integrating the product Realization Process (PRP) into the Undergraduate Curriculum, A Curriculum Development Project of the ASME Council on Education,. ASME December 1995.

Devon, Richard, "Toward a Social Ethics of Engineering: The Norms of Engagement", Engineering Education, Vol. 88, No. 1, p. 87, January 1999.

Marra, Rose M, Palmer, Betsy, and Litzinger, Thomas A, "The Effects of a First-Year Engineering Design Course on Student Intellectual Development as Measured by the Perry Scheme, Engineering Education, Vol. 89, No.1, p 39, January 2000,

${ }^{7}$ See for example:

Catalano, George D., and Catalano, Karen, Transformation: From Teacher -Centered to Student-Centered Engineering Education, Engineering Education, Vol. 88, No. 1, p 59, January 1999.

Croissant, Jennifer L., Ogden, Kimberly, and Ogden, Gregory, "Teamed Internship in environmental Engineering and Technology; A project Report, Engineering Education, Vol. 89, No. 2, p. 111, April 2000,

Haller, Cynthia, R. Gallagher, Victoria J., Weldon, Tracey L., and Felder, Richard M. "Dynamics of Peer Education in cooperative Learning Workgroups, Engineering Education, Vol. 89, No. 3, p 285, July 2000.

${ }^{8}$ Examples include California Institute of Technology, Stanford University, University of Maryland, College Park, University of Wisconsin, Madison, University of Illinois at Urbana-Champaign, and the Massachusetts Institute of Technology.

${ }^{9}$ The question examined by the committee was somewhat more detailed:

What (if anything) should the College of Engineering do in Engineering Entrepreneurship?

-For engineering students with special interests in Engineering Entrepreneurship

-For all engineering students

- Students with interests in graduate study in engineering

- Students with interest in working in large corporations

- Students with interest in working in small business

This paper, however, will not discriminate between the subsets of students.

Proceedings of the 2001 American Society for Engineering Education Annual Conference \& Exposition Copyright 2001, American Society for Engineering Education. 
${ }^{10}$ Members of the Engineering Foundation Advisory Council.

${ }^{11}$ See www.abet.org.

${ }^{12}$ Mechanical Engineering in the $21^{\text {st }}$ Century: Trends Impacting the Profession, A Report Prepared for the Committee on Issues Identification, Council on Public Affairs, The American Society of Mechanical

Engineering, Prepared by the Hudson Institute, Inc., September 1999.

${ }^{13}$ Id., $\mathrm{p}$

${ }^{14}$ Id., p 11.

15 Id., p 92.

${ }^{16}$ Id., p 88.

${ }^{17}$ Nichols, Steven P. and Weldon, William F., Professional Responsibility: The Role of the Engineering in Society: Science and Engineering Ethics, Vol. 3, p 327-337.

${ }^{18}$ Davis, Michael, Integrating Ethics into Technical Courses: IIT's Experience in its Second Year, Frontiers in Education Conference, IEEE/ASEE: 64, 1992.

\section{STEVEN P. NICHOLS}

Dr. Steven P. Nichols is Associate Professor and an Associate Chair in the Department of Mechanical Engineering at The University of Texas at Austin. He also serves as the Director of the Design Projects program. Dr. Nichols is a Professional Engineer registered in Texas and is an Attorney at Law licensed in Texas. Dr. Nichols received his Ph.D. in 1975 and his J.D. in 1983.

\section{NEAL E. ARMSTRONG}

Dr. Neal E. Armstrong is Associate Dean for Academic Affairs in the College of Engineering, Zarrow Centennial Professor in Engineering, and Professor of Civil Engineering at The University of Texas at Austin. $\mathrm{He}$ is a Professional Engineer registered in Texas. Dr. Armstrong received his Ph.D. in Engineering in 1968. 